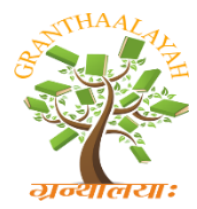

INTERNATIONAL JOURNAL OF RESEARCH GRANTHAALAYAH A knowledge Repository

Science

\title{
RETROSPECTIVE ANALYSIS OF INTRACRANIAL AND INTRASPINAL SPACE OCCUPYING LESIONS AT A TERTIARY CARE CENTER- A FIVE YEAR STUDY
}

\author{
Meena B. Patil *1, Manjiri N. Karandikar ${ }^{2}$ \\ ${ }^{* 1}$ MD(Pathology) Associate Professor, Department of Pathology, Bharati Vidyapeeth (Deemed \\ to be University) Medical College, Pune, Maharashtra, India \\ ${ }^{2}$ MD(Pathology) Professor, Department of Pathology, Bharati Vidyapeeth (Deemed to be \\ University) Medical College, Pune, Maharashtra, India
}

\begin{abstract}
Background: Tumors of Central Nervous System constitute approximately $2 \%$ of all malignancies. Cancers of the central nervous system (CNS) are considered to be among the most notorious of all cancers. Low-grade cns tumors have been found over time to progress to high grade tumors. CNS is a common site for metastasis from other organs. Due to newer techniques used in radio diagnosis and stereotactic biopsies, more \& more CNS tumors are being diagnosed $\&$ are being operated upon.
\end{abstract}

Aims and objectives: The objective of this article is to provide an overview of intracranial and intraspinal space occupying lesions at a single tertiary care referral center. The aim was to study incidence of various lesions in light of the WHO classification of tumours of the central nervous system, 2016 and to study relevant statistics.

Material and methods: A total of 124 cases were received between January,2007 \& December, 2011 at Bharati Vidyapeeth Deemed University Medical College and Hospital, Pune. Intraoperative diagnosis was desired in 70 cases. The final diagnoses in all the cases were made on Hematoxylin and Eosin stained slides of routinely processed tissue.

Results: Neoplastic lesions comprised $83.88 \%$, including metastatic tumors while $16.12 \%$ were nonneoplastic. A wide range of histopathological spectrum of CNS tumors was observed and was classified according to WHO classification of CNS tumors, 2016. The primary CNS tumors were graded from Grade I to IV according to WHO grading system, 2016. Astrocytic tumors constituted the largest category with 33 cases and most of the astrocytomas were grade II at the time of diagnosis. Incidence was more in females than males and maximum number of lesions were seen in fifth and sixth decades of life.

Conclusion: This study highlights the histological diversity of CNS tumors in both adults and children. The most common destructive but nonneoplastic lesions like, infections/abscesses, infarct and cysts can be diagnosed, by crush cytology and frozen section for the definitive management.

Keywords: Astrocytoma; CNS Tumors; Crush Cytology; Frozen Section. 
Cite This Article: Meena B. Patil, and Manjiri N. Karandikar. (2018). "RETROSPECTIVE ANALYSIS OF INTRACRANIAL AND INTRASPINAL SPACE OCCUPYING LESIONS AT A TERTIARY CARE CENTER- A FIVE YEAR STUDY." International Journal of Research Granthaalayah, 6(10), 100-109. https://doi.org/10.29121/granthaalayah.v6.i10.2018.1167.

\section{Introduction}

Central nervous system tumors are not very common. However, the incidence of CNS tumors has rapidly increased over the past few years. ${ }^{1,2}$ The incidence of CNS tumors in India ranges from 5 to 10 per 100,000 population with an increasing trend and accounts for $2 \%$ of all malignancies. ${ }^{3,4}$ This substantial increase in diagnosis of CNS tumors is mostly attributed to advances in neuroimaging technology. ${ }^{4}$ Some of the most important intraoperative diagnoses in neurosurgery are the diagnoses of nonneoplastic lesions because patients with such lesions often do not benefit from resection. The most common destructive but nonneoplastic lesions that mimic neoplasia clinically and radiologically are infections/abscesses, infarcts \& plaques of demyelinating diseases like multiple sclerosis. $5,6,7$

The objective of this study is to provide an overview of central nervous system tumors in a tertiary hospital set up. Aim was to study incidence of various lesions in light of the WHO classification of tumours of the central nervous system, $2016^{8}$ and to study relevant statistics. In developing countries like India, due to lack of complete registration of newly diagnosed cancer cases with local registries, the exact tumor burden of such diseases goes unnoticed and is underestimated. Hospital-based prevalence data, therefore forms the basis for estimating the disease load. ${ }^{9}$

In the present study the spectra of the CNS tumors were different in the pediatric and adult age groups. In adults, astrocytic tumors and tumors of meninges were more common. In children, astrocytic tumors and embryonic tumors took the lead. The data collected are further analyzed in the following paper.

\section{Material and Methods}

A retrospective study of biopsy specimens received at the Department of Pathology, Bharati Vidyapeeth Deemed University Medical College \& Hospital, Pune from January 2007 to December 2011 was carried out. A total 124 biopsy specimens of intracranial and intraspinal space occupying lesions were received. In 70 specimens, an intraoperative diagnosis was desired. In all the specimens, crush cytology \&frozen section were done. The rest of the specimen was submitted for routine histopathology. Routine tissue processing was done and the slides were stained with Hematoxylin \& Eosin. Histological classification and grading of these tumors was done as per WHO classification of tumours of the central nervous system, 2016. The incidence of the tumors over a five year period and the distribution based on age, sex and location were analyzed.

\section{Results/Observations}

The study was conducted for a 5 year period in which 124 cases of intracranial \& intraspinal space occupying lesions were studied. Out of 124 cases clinically diagnosed as intracranial space occupying lesions, 104 cases showed neoplastic lesions while 20 cases were nonneoplastic. 
The various symptoms noted were headache, nausea, vomiting, slurring of speech, blurring of vision, diplopia, seizures, weakness of limbs and paraparesis. Duration of symptoms in 108 cases was less than 6 months \& in 16 cases it was more than 6 months.

The CNS lesions showed a slight female predominance; males $(n=56)$ and female $(n=68)$. Astrocytoma was commoner in males whereas meningioma was commoner in females. For craniopharyngioma, pituicytoma, medulloblastoma \& PNET the M: F ratio was 1:1.

Age distribution seen in our study revealed that tumors were more common in the age group of $41-50$ years $(n=27)$, followed by 51-60 years $(n=26)$. The youngest patient was 18 month old while the oldest patient was 75 years of age. Tumors had predilection for cerebral hemisphere in pediatric as well as adult patients. [Table1].

Age group from 0-10years showed presence of 21 cases of neoplastic lesions, among which astrocytoma and medulloblastoma were maximum. Age group of 41-50years showed 26 neoplastic lesions with predominance of meningioma $\&$ astrocytoma. [Table 2]. We observed that out of 104 neoplastic lesions, grade I lesions were the commonest $(n=56)$ followed by grade II lesions $(n=23)$. [Table 3].

Among the CNS tumors, $88 \%$ presented as intracranial lesions and only $12 \%$ were intraspinal lesions. Among the nonneoplastic lesions $75 \%$ were detected as intracranial lesions \& $25 \%$ as intraspinal lesions.

Correlation of crush cytology, frozen section and routine paraffin embedded sections was done in 70 cases. The results were as follows. 61 turned out to be neoplastic lesions while 9 were nonneoplastic lesions. Eight cases showed correlation between cytology, frozen section and routine H\&E in nonneoplastic lesions while one case did not correlate. [Table 4 A]. Sixty cases showed correlation between cytology, frozen section \& routine H\&E in neoplastic lesions while one case did not correlate. (Table $4 \mathrm{~B}$ ).

The different nonneoplastic lesions found during the study were arachnoid cyst, brain abscess, epidermoid cyst, cerebral infarct, mucocele, and tuberculoma. [Table 5]

Table 1: Distribution of lesions according to site in different age groups

\begin{tabular}{|l|l|l|l|l|l|l|l|l|l|l|}
\hline \multicolumn{10}{|c|}{ Age in years } \\
\hline Sr.No. & Site of lesion & $\mathbf{0 - 1 0}$ & $\mathbf{1 1 - 2 0}$ & $\mathbf{2 1 - 3 0}$ & $\mathbf{3 1 - 4 0}$ & $\mathbf{4 1 - 5 0}$ & $\mathbf{5 1 - 6 0}$ & $\mathbf{6 1 - 7 0}$ & $\mathbf{7 1 - 8 0}$ & Total \\
\hline 1 & Cerebral hemisphere & 12 & 03 & 07 & 04 & 11 & 15 & 01 & 01 & 54 \\
\hline 2 & Cerebellum & 03 & 02 & 02 & 003 & 01 & 02 & 00 & 00 & 13 \\
\hline 3 & CP angle & 00 & 00 & 04 & 05 & 03 & 02 & 01 & 00 & 15 \\
\hline 4 & $3^{\text {rd }} / 4^{\text {th }}$ Ventricle & 03 & 01 & 00 & 00 & 03 & 00 & 00 & 00 & 07 \\
\hline 5 & Sellar \& suprasellar & 02 & 01 & 03 & 01 & 04 & 01 & 00 & 00 & 12 \\
\hline 6 & Optic nerve/Orbit & 00 & 01 & 01 & 00 & 00 & 00 & 00 & 00 & 02 \\
\hline 7 & Sphenoid region & 00 & 01 & 00 & 00 & 00 & 01 & 00 & 00 & 02 \\
\hline 8 & Spinal cord & 02 & 01 & 02 & 02 & 04 & 05 & 00 & 00 & 16 \\
\hline 9 & Pineal region & 01 & 01 & 00 & 00 & 00 & 00 & 01 & 00 & 03 \\
\hline & Total & $\mathbf{2 3}$ & $\mathbf{1 1}$ & $\mathbf{1 9}$ & $\mathbf{1 5}$ & $\mathbf{2 6}$ & $\mathbf{2 6}$ & $\mathbf{0 3}$ & $\mathbf{0 1}$ & $\mathbf{1 2 4}$ \\
\hline
\end{tabular}


Table 2: Incidence of various lesions in different age groups

\begin{tabular}{|l|l|l|l|l|l|l|l|l|l|l|}
\hline \multicolumn{9}{|c|}{ Age in years } \\
\hline Sr. No. & Type of lesion & $\mathbf{0 - 1 0}$ & $\mathbf{1 1 - 2 0}$ & $\mathbf{2 1 - 3 0}$ & $\mathbf{3 1 - 4 0}$ & $\mathbf{4 1 - 5 0}$ & $\mathbf{5 1 - 6 0}$ & $\mathbf{6 1 - 7 0}$ & $\mathbf{7 1 - 8 0}$ \\
\hline 1 & $\begin{array}{l}\text { Diffuse astrocytic \& } \\
\text { Oligodendroglial tumors }\end{array}$ & 03 & 01 & 02 & 04 & 06 & 09 & 00 & 01 \\
\hline 2 & Other astrocytic tumors & 04 & 02 & 01 & 00 & 01 & 01 & 00 & 00 \\
\hline 3 & Ependymal tumors & 01 & 00 & 00 & 00 & 00 & 00 & 00 & 00 \\
\hline 4 & Other gliomas & 00 & 00 & 01 & 00 & 00 & 00 & 00 & 00 \\
\hline 5 & Choroid plexus tumors & 01 & 00 & 00 & 00 & 00 & 00 & 00 & 00 \\
\hline 6 & Tumors of pineal region & 01 & 00 & 01 & 00 & 00 & 01 & 00 & 00 \\
\hline 7 & Embryonal tumors & 03 & 02 & 01 & 00 & 00 & 00 & 00 & 00 \\
\hline 8 & $\begin{array}{l}\text { Tumors of cranial \& } \\
\text { spinal nerves }\end{array}$ & 00 & 01 & 04 & 08 & 04 & 05 & 01 & 00 \\
\hline 9 & Meningiomas & 00 & 00 & 00 & 02 & 09 & 03 & 00 & 00 \\
\hline 10 & $\begin{array}{l}\text { Nonmeningothelial } \\
\text { tumors }\end{array}$ & 02 & 02 & 01 & 00 & 02 & 01 & 00 & 00 \\
\hline 11 & Melanocytic tumors & 00 & 01 & 00 & 00 & 00 & 00 & 00 & 00 \\
\hline 12 & Tumors of sellar region & 01 & 01 & 03 & 02 & 00 & 01 & 00 & 00 \\
\hline 13 & Metastatic tumors & 00 & 00 & 01 & 01 & 00 & 02 & 01 & 00 \\
\hline 14 & Nonneoplastic lesions & 05 & 02 & 04 & 02 & 05 & 02 & 00 & 00 \\
\hline & Total & $\mathbf{2 1}$ & $\mathbf{1 1}$ & $\mathbf{1 9}$ & $\mathbf{1 8}$ & $\mathbf{2 6}$ & $\mathbf{2 6}$ & $\mathbf{0 2}$ & $\mathbf{0 1}$ \\
\hline
\end{tabular}

Table 3: Grading of Primary CNS tumors according to WHO classification of CNS tumors, 2016

\begin{tabular}{|l|l|l|l|l|l|}
\hline Sr. No. & \multicolumn{1}{|c|}{ Diagnosis } & Grade I & Grade II & Grade III & Grade IV \\
\hline I) & Diffuse astrocytic \& oligodendroglial tumors & & & & \\
\hline 1. & Diffuse astrocytoma & & 15 & & \\
\hline 3. & Glioblastoma & & & & 7 \\
\hline 2. & Anaplastic astrocytoma & & 1 & & \\
\hline 4. & Oligodendroglioma & & & & \\
\hline II) & Other astrocytic tumors & 5 & & & \\
\hline 1. & Pilocytic astrocytoma & & 3 & & \\
\hline $\mathbf{2 .}$ & Pleomorphic xanthoastrocytoma & 1 & & & \\
\hline 3. & Pilomyxoid astrocytoma & & & & \\
\hline III) & Ependymal tumors & & 1 & & \\
\hline 1. & Ependymoma & & & & \\
\hline IV) & Other gliomas & & 1 & & \\
\hline 1. & Astroblastoma & & & & \\
\hline V) & Choroid plexus tumors & 1 & & & \\
\hline 1. & Choroid plexus papilloma & & & & \\
\hline VI) & Tumors of pineal region & 1 & & & \\
\hline 1. & Pineocytoma & & 1 & & \\
\hline 2. & $\begin{array}{l}\text { Pineal parenchymal tumor of intermediate } \\
\text { differentiation }\end{array}$ & & 1 & & \\
\hline 3. & Papillary tumor of pineal region & & & & \\
\hline VII) & Embryonal tumors & & & \\
\hline 1. & Medulloblastoma & & & \\
\hline VIII) & Tumors of cranial \& spinal nerves & & & \\
\hline 1. & Schwannoma & & & \\
\hline
\end{tabular}




\begin{tabular}{|l|l|l|l|l|l|}
\hline 2. & Neurofibroma & 3 & & & \\
\hline IX) & Meningiomas & & & & \\
\hline 1. & Meningioma & 12 & & & \\
\hline 2. & Atypical meningioma & & 1 & & \\
\hline 3. & Anaplastic meningioma & & & 1 & \\
\hline X) & Nonmeningothelial tumors & & & & \\
\hline 1. & Hemangioblastoma & 3 & & & \\
\hline 2. & PNET & & & & 4 \\
\hline 3. & Hemangiopericytoma & 1 & & & \\
\hline XI) & Melanocytic tumors & 1 & & & \\
\hline IX) & Tumors of sellar region & & & & \\
\hline 1. & Craniopharyngioma & 4 & & & \\
\hline 2. & Pituicytoma & 4 & & & $\mathbf{0 2}$ \\
\hline Total & & $\mathbf{5 6}$ & $\mathbf{2 4}$ & $\mathbf{0 2}$ \\
\hline
\end{tabular}

Table 4 A): Correlation between cytology, frozen section and routine H\&E in nonneoplastic lesions

\begin{tabular}{|l|l|l|l|}
\hline Nonneoplastic lesions & Cytology \& frozen section & Routine H\&E & Percentage \\
\hline Correlated & 8 & 8 & 88.88 \\
\hline Noncorrelated & 1 & 1 & 11.22 \\
\hline
\end{tabular}

Table 4 B): Correlation between cytology, frozen section \& routine H\&E in neoplastic lesions

\begin{tabular}{|l|l|l|l|}
\hline Neoplastic lesions & Cytology \& frozen section & Routine H \&E & Percentage \\
\hline Correlated & 60 & 60 & 98.3 \\
\hline Noncorrelated & 1 & 1 & 1.7 \\
\hline
\end{tabular}

\section{Causes of Errors of Interpretation}

The tissue sent for intraoperative diagnosis did not represent the actual lesion. Presence of multinucleate giant cells, spindle shaped cells and lymphocytes posed a diagnostic problem between a tuberculoma and a pleomorphic xanthoastrocytoma.

Table 5: Nonneoplastic lesions according to age, sex \& site

\begin{tabular}{|l|l|l|l|l|l|}
\hline Age (yrs) & M & \multicolumn{1}{|c|}{ F } & \multicolumn{1}{|c|}{ Sites of lesions } & \multicolumn{1}{|c|}{ Diagnosis } & Total \\
\hline $0-10$ & 1 & 1 & Sacrococcygeal & Meningomyelocele & 2 \\
\hline $11-20$ & 5 & 0 & Cerebrum & Brain abscess & 5 \\
\hline $21-30$ & 0 & 0 & NA & NA & 0 \\
\hline $31-40$ & 2 & 5 & $\begin{array}{l}\text { CP angle, Cerebrum, } \\
\text { D2-L5, Intradural }\end{array}$ & Epidermoid cyst & 7 \\
\hline $41-50$ & 4 & 2 & $\begin{array}{l}\text { Lat. Ventricle, Cerebrum } \\
\text { Base of skull } \\
\text { D7- D8, intraxial }\end{array}$ & $\begin{array}{l}\text { Arachnoid cyst, Cerebral infarct, } \\
\text { Infiltrating cholesteatoma, Tuberculoma }\end{array}$ & 6 \\
\hline
\end{tabular}

There was no case beyond 50 years of age in nonneoplastic group.

\section{Discussion}

The incidence of central nervous system (CNS) tumors in India ranges from 5 to 10 per 100,000 population with an increasing trend and accounts for $2 \%$ of malignancies. ${ }^{3,4}$ Tumors of CNS 
account for $20 \%$ of all cancers of childhood. $70 \%$ of childhood CNS tumors arise in the posterior fossa. A considerable number of tumors in adults arise within the cerebral hemisphere above the tentorium. $^{10}$

The relative frequency of various intracranial tumors is different in adults and in children. In both the adults and children the most common intracranial tumor is an astrocytoma. Second in frequency are meningeal tumors in adults and embryonal tumors in children. Tumors of cranial and paraspinal nerves are mostly schwannomas and are seen in adults.

The distinction between benign and malignant lesions is less evident in the CNS as compared to other organs. Brain tumors are graded on the basis of their histological characteristics from grade I to IV, according to WHO grading system providing an approximate prognostic guide. In our study maximum lesions were grade I.

The nonneoplastic lesions encountered in the study were, arachnoid cysts, brain abscess, epidermoid cysts, cerebral infarcts, mucocele, meningomyelocele and tuberculoma.

Out of 124 cases in our study 104 lesions were neoplastic and remaining 20 lesions were nonneoplastic. The comparison of our findings with other studies in terms of neoplastic and nonneoplastic lesions is shown in the following table. ${ }^{11.12 .13}$

\begin{tabular}{|c|c|c|c|c|c|c|c|c|c|c|}
\hline $\begin{array}{l}\text { Nature of } \\
\text { lesion }\end{array}$ & \multicolumn{2}{|c|}{$\begin{array}{c}\text { Torres et al } \\
\text { (1993) } \\
\text { Number \% }\end{array}$} & \multicolumn{2}{|c|}{$\begin{array}{c}\text { Di Stetano et } \\
\text { al } \\
(1998) \\
\text { Number \% }\end{array}$} & \multicolumn{2}{|c|}{$\begin{array}{c}\text { Jain D et al } \\
(2007) \\
\text { Number } \%\end{array}$} & \multicolumn{2}{|c|}{$\begin{array}{c}\text { Bashir A et al } \\
\text { (2014) } \\
\text { Number \% }\end{array}$} & \multicolumn{2}{|c|}{$\begin{array}{c}\text { Present study } \\
\text { Number } \%\end{array}$} \\
\hline Nonneoplastic & 20 & 16.52 & 11 & 12.94 & 5 & 7.14 & 35 & 17.5 & 20 & 16.2 \\
\hline Neoplastic & 287 & 83.48 & 74 & 87.05 & 65 & 92.85 & 165 & 82.5 & 104 & 83.8 \\
\hline Total & 307 & 100 & 85 & 100 & 70 & 100 & 200 & 100 & 124 & 100 \\
\hline
\end{tabular}

Astrocytic tumors being the most common lesion found in this study, it is worthwhile analyzing the cases of astrocytoma using various parameters as shown in the table below:

\begin{tabular}{|l|l|l|l|l|l|}
\hline \multicolumn{1}{|c|}{ Type of astrocytoma } & $\begin{array}{l}\text { Number of } \\
\text { cases }\end{array}$ & \multicolumn{1}{|c|}{ Site } & Male & Female \\
\hline Pilocytic Astrocytoma & 5 & $\begin{array}{l}\text { Post. fossa, } \\
\text { Suprasellar, Cerebrum }\end{array}$ & $\begin{array}{l}\text { First 2 decades } \\
\& 55 \text { yrs }\end{array}$ & 2 & 3 \\
\hline Pilomyxoid Astrocytoma & 1 & IVth ventricle & 5 yrs & 0 & 1 \\
\hline $\begin{array}{l}\text { Diffuse Fibrillary } \\
\text { Astrocytoma }\end{array}$ & 15 & $\begin{array}{l}\text { Cerebrum } \\
\text { D9-L1 Intramedullary }\end{array}$ & $1^{\text {st }}$ to $7^{\text {th }}$ decades & 10 & 5 \\
\hline Anaplastic Astrocytoma & 1 & Cerebrum & 45 yrs & 1 & 0 \\
\hline Glioblastoma & 7 & Cerebrum & $\begin{array}{l}5^{\text {th }} \& 6^{\text {th }} \text { decades } \\
\& 18 \text { years }\end{array}$ & 3 & 4 \\
\hline Oligodendroglioma & 1 & Cerebrum & 40 yrs & 0 & 1 \\
\hline $\begin{array}{l}\text { Pleomorphic } \\
\text { xanthoastrocytoma }\end{array}$ & 3 & Cerebrum & $\begin{array}{l}1^{\text {st }} \text { \& 2nd } \\
\text { decades }\end{array}$ & 0 & 3 \\
\hline Total & $\mathbf{3 3}$ & & & $\mathbf{1 6}$ & $\mathbf{1 7}$ \\
\hline
\end{tabular}

Although most of the lesions were seen in the same age groups and the same sites as described in the literature, there were some unusual findings which have been highlighted in the following 
paragraphs. Pilocytic astrocytoma which is a childhood tumor occurring in posterior fossa was found in a 55 year female, in the parietal lobe.

There has been a lot of debate over the grading of pilomyxoid astrocytoma and whether it is an entity distinct from pilocytic astrocytoma. We would like to put on record that there was recurrence of pilomyxoid astrocytoma in a 5 year old girl.

Biological behavior of pleomorphic xanthoastrocytoma depends on extent of resection and the number of mitotic figures. Five or more mitoses/10hpf is a bad prognostic indicator. The case of recurrent PXA in the study group did not show increased mitosis.

Although cerebral glioblastoma can occur at any age, they are most frequent after 50 years of age, but a few cases may occur in younger age group as is the occurrence of a glioblastoma at 18 years of age in this study.

When there are a large number of monstrous tumour giant cells in a glioblastoma, it is termed as giant cell glioblastoma. Giant cell glioblastoma are much firmer in consistency and are localized due to presence of intercellular reticulin. A case of giant cell glioblastoma was seen with H/o recurrence in a $57 \mathrm{yr}$ old male.

A case of astroblastoma was seen in a $26 \mathrm{yr}$ female patient. Whether astroblastoma is a distinct clinicopathological entity was not clear for a long time. WHO classification of the central nervous system tumours, 2016 has included astroblastoma in 'other gliomas' group and has been allotted grade II.

Following table highlights differences between astroblastoma \& ependymoma.

\section{Contrasting features between astroblastoma \& ependymoma}

\begin{tabular}{|c|c|c|}
\hline & Astroblastoma & Ependymoma \\
\hline Age & First three decades & Children \& adolescent \\
\hline $\mathrm{C} / \mathrm{F}$ & Headache, seizures & Seizures with focal motor deficit \\
\hline Site & Cerebral hemisphere & $60-70 \%$ Infratentorial \\
\hline $\begin{array}{l}\text { Gross } \\
\text { features }\end{array}$ & $\begin{array}{l}\text { Well defined solid mass, c/s } \\
\text { homogeneous, cysts \& necrosis }+\end{array}$ & $\begin{array}{l}\text { Lobulated exophytic mass hanging from the } \\
\text { ventricular lining }\end{array}$ \\
\hline $\begin{array}{l}\text { Microscopic } \\
\text { features }\end{array}$ & $\begin{array}{l}\text { Club shaped cells loosely arranged } \\
\text { around blood vessels; cytoplasmic } \\
\text { processes are short \& stout or may be } \\
\text { slightly tapering. Nuclei often } \\
\text { angulated \& hyperchromatic. }\end{array}$ & $\begin{array}{l}\text { Perivascular pseudorosettes \& ependymal } \\
\text { tubules. } \\
\text { Cell borders ill defined \& nuclei appear } \\
\text { embedded in fibrillar background. Nuclei } \\
\text { uniform, round to oval with delicate } \\
\text { chromatin. Equidistant from blood vessels } \\
\text { with fibrillary processes occupying the } \\
\text { intervening zones. }\end{array}$ \\
\hline
\end{tabular}


A case of intracranial SOL in a 57 year male was diagnosed as keratoma with extraaxial spread to the base of brain. He was having past history of tympanoplasty.

Papillary tumor of pineal region is a rare entity. This tumor was introduced in WHO classification 2007 for the first time and is thought to derive from specialized ependymocytes of the subcommisural organ. Local recurrence is known to occur \& our case was a recurrent tumor after the previous surgery two years back.

Pineal parenchymal tumor of intermediate differentiation (PPTID) was seen in a 25 year female with h/o recurrence after 3 years. She presented with metastases in thoracic and lumbosacral spinal regions. This is a rare event. PPTID was recognized in the 2007 World Health organization (WHO) classification as a new pineal parenchymal neoplasm intermediate in malignancy (WHO grade II and III) between pineocytoma (Grade I) and pineoblastoma (Grade IV). It occurs at all ages, from childhood to adult life, with a peak incidence in early adults. PPTIDs are more aggressive than pineocytomas and commonly present with local infiltration \& distant CSF dissemination.

Another case of pineal parenchymal tumor of intermediate differentiation was a $8 \mathrm{yr}$ female who presented as a posterior fossa tumor.

The following table shows the details of pineal parenchymal tumors:

\begin{tabular}{|l|l|l|l|l|}
\hline \multicolumn{1}{|c|}{ Type } & No. & \multicolumn{1}{c|}{ Site } & Age in years & Sex \\
\hline Pineal parenchymal tumor of intermediate differentiation & 1 & Post. fossa & 25 & F \\
\hline Pineal parenchymal tumor of intermediate differentiation & 1 & Pineal region & 8 & F \\
\hline Papillary tumor of pineal region & 1 & Pineal region & 60 & F \\
\hline
\end{tabular}

Secondary involvement of the CNS by direct extension or hematogenous metastasis is a common complication of systemic cancer and a phenomenon that frequently prompts diagnostic, as well as a palliative neurosurgical intervention.

The following table shows the details of metastatic lesions: Frontal lobe of cerebral hemisphere the was common site for metastasis.

\begin{tabular}{|l|l|l|l|l|l|}
\hline $\begin{array}{c}\text { Sr. } \\
\text { No. }\end{array}$ & $\begin{array}{c}\text { Age in } \\
\text { years }\end{array}$ & Sex & $\begin{array}{c}\text { Primary } \\
\text { site }\end{array}$ & $\begin{array}{c}\text { Metastasis Site of } \\
\text { lesion }\end{array}$ & \multicolumn{1}{c|}{ Primary Lesion } \\
\hline 1. & 40 & F & Kidney & Frontal lobe & Clear cell Renal cell carcinoma \\
\hline 2. & 55 & F & Lung & Frontal lobe & $\begin{array}{l}\text { Mucin secreting papillary } \\
\text { adenocarcinoma }\end{array}$ \\
\hline 3. & 70 & M & Prostate & Frontal lobe & Adenocarcinoma \\
\hline 4. & 22 & M & Testis & Frontal lobe & Yolk sac tumor (NSGCT) \\
\hline 5. & 60 & F & Thyroid & D9-D10 vertebrae & Papillary Carcinoma of thyroid \\
\hline
\end{tabular}

As this study is a single center series, the data in this study may not represent the national epidemiological data of central nervous system tumors. This study may help in monitoring disease patterns and changing trends. The data from this study may provide valuable information regarding CNS tumor spectrum for future research and planning. 


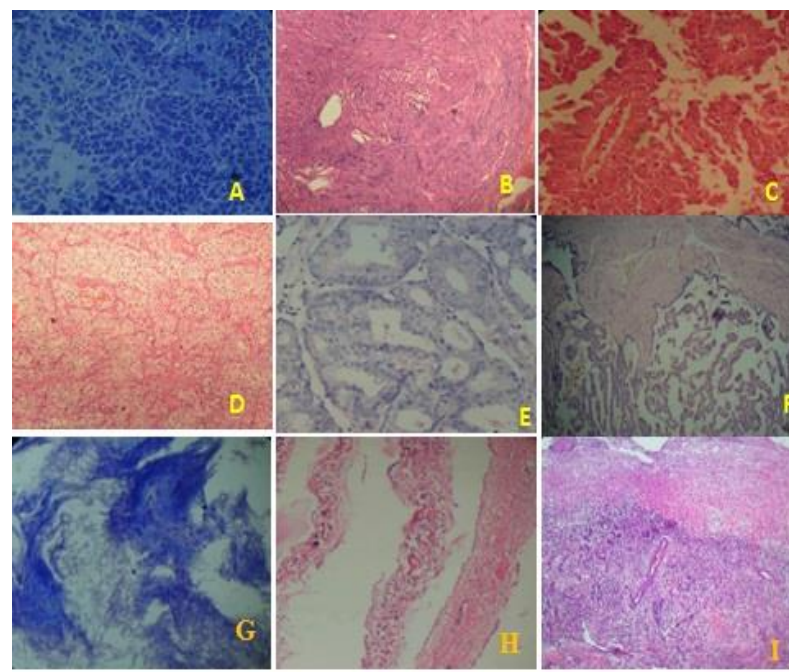

Figure 1: A. Medulloblastoma, B. Schwanoma, C. Papillary tumour of pineal region, D. Metastastatic clear cell carcinoma, E. Metastatic adenocarcinoma, F. Choroid plexus papilloma, G. Epidermal cyst, H. Arachnoid cyst, I. Brain infarct

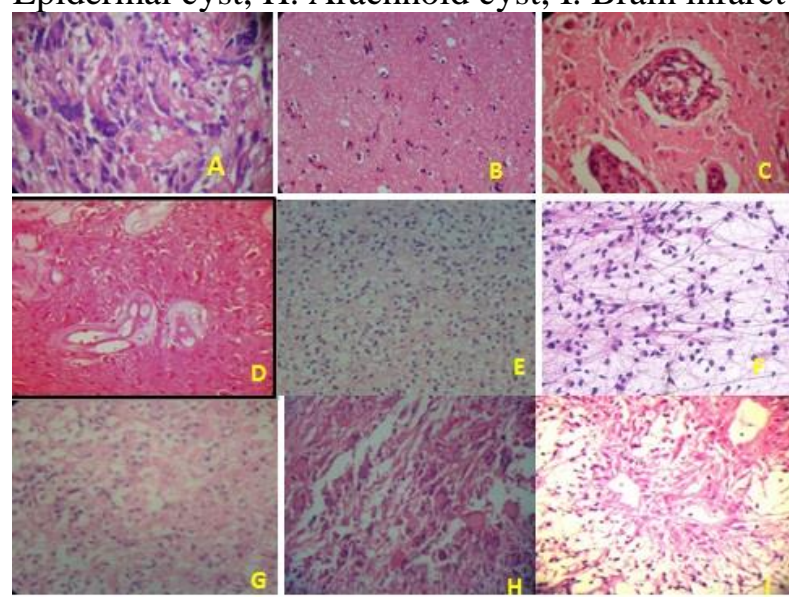

Figure 3: A. PXA, B. Diffuse fibrillary astrocytoma, C. GBM, D. Rosenthal fiber rich astrocytoma, E. Oligodendroglioma, F. Pilocytic astrocytoma, G. Gemistocytic astrocytoma, H. Giant cell glioblastoma, I. Pilomyxoid astrocytoma

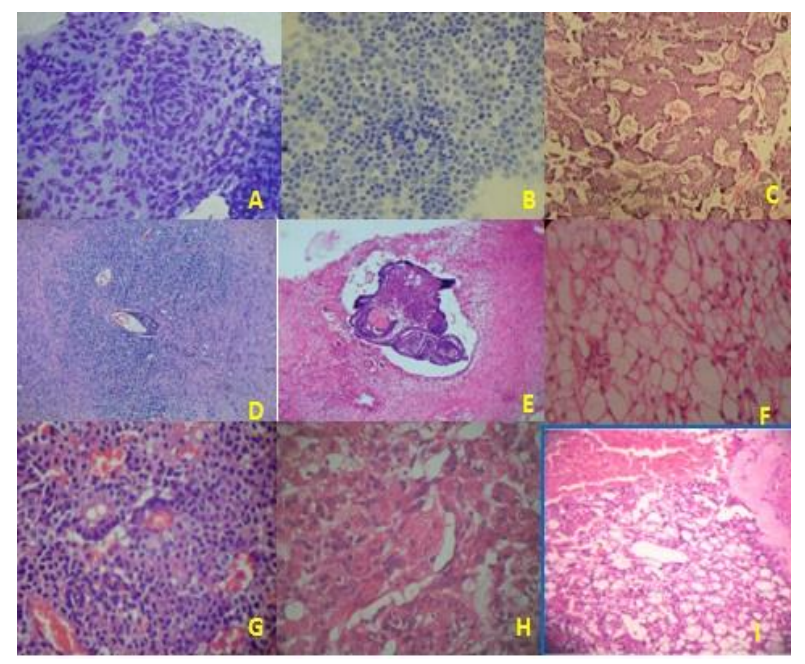

Figure 2: A. Meningioma, B. Pineocytoma, C. Meningeal hemangiopericytoma, D. PNET, E. Craniopharyngioma, F. Clear cell meningioma, G. Pitutary adenoma, H. Atypical meningioma, I. Hemangioblastoma
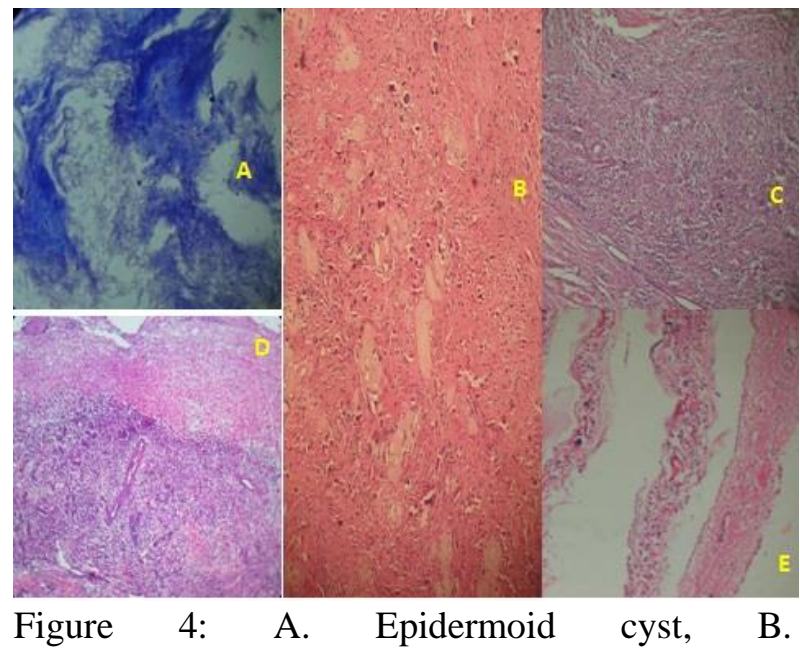

Meningomyelocele, C. Brain abcess, D. Brain Infarct, E. Arachnoid cyst

\section{Conclusion}

The present study highlights the histological diversity in CNS tumors in both, adult as well as pediatric age groups. A retrospective epidemiological review of brain tumors is particularly important for future research because it can demonstrate the changes in the tumor spectrum of a population. It can reveal possible risk factors. Further multicentric studies need to be conducted to have substantial data for use in future.

Crush cytology is useful in diagnosing gliomas, medulloblastomas \& pituicytomas but has a limited role in diagnosis of schwannomas, meningiomas (fibroblastic), and craniopharyngiomas 
as they are resistant to smear. Frozen sections are useful in differentiating low grade astrocytomas from normal brain \& reactive gliosis and are helpful in diagnosing craniopharyngiomas.

Correlation of clinical, radio imaging findings \& with crush cytology \& frozen sections must be done during intra-operative diagnosis.

\section{References}

[1] Bauchet L, Rigau V, Mathieu-Daude H, Figarella-Branger D, Hugues D, Palusseau L, et al. French Brain tumor data bank:methodology and first results on 10,000 cases. J Neurooncol.2007; 84(2):8999

[2] Kaneko S, Nomura K, and Yoshimura T, Yamaguchi N: Trend of brain tumor incidence by histological subtypes in Japan: estimation from the Brain Tumor Registry of Japan, 1973-1993. J. neurooncol. 2002; 60(1):61-9

[3] Nair M, Varghese C, Swaminathan R. Cancer: Current scenario, Intervention Strategies and projections for 2015. NCMH Background Papers; 2015.

[4] Yeole BB. Trends in the brain cancer incidence in India. Asian Pac J Cancer Prev 2008; 9:267-70.

[5] Toxy J, Hussain A, Montag A. Central Nervous System. In: Biopsy Interpretation: The Frozen section. Philadelphia: Lipincott Williams \& Williams; 2010.303-309

[6] Ironside JW. Update on Central Nervous System Cytopathology. Brain Smear technique. Journal of Clin Pathol. 1994, March 29; 47:683-688

[7] Adams JH, Graham DI, Doyle D. Brain biopsy. The smear technique for neurosurgical biopsies.London: Chapman and Hall, 1981

[8] The 2016 World Health Organization Classification of Tumors of the Central Nervous System: a summary. Acta Neuropathologica, June 2016, Volume 131, Issue 6, p.803-820

[9] Jain A, Sharma MC, Suri V, Kale SS, Mahapatra AK, Tatke M, et al. Spectrum of pediatric brain tumors in India: A multi-institutional study. Neurol India 2011; 59:208-11

[10] Kumar V, Abbas AK, John C. Aster. The Central Nervous System. In; Robbins and Cortan Pathologic Basis of Disease-Vol II. South Asia Edition. 2014 Reed Elsevier India Pvt. Ltd. P.1306

[11] Di Stefano D, Scucchi LF, Cosentino L, Bosman C, Veahione. Intraoperative Diagnosis of nervous system lesions. Acta cytol. 1998, 42:346-356

[12] Torres LFB, Collaco LM. Smear technique for the intraoperative examination of nervous system lesions, Acta cytol.1993, and 37:34-39

[13] Jain D, Sharma M, Sarkar C, Deb P, Gupta D, Mahapatra AK. Correlation of diagnostic yield of stereotactic brain biopsy with number of biopsy bits and site of the lesion. Brain Tumor Pathology. Vol 23, No.2. 2007:71-75

\footnotetext{
*Corresponding author.

E-mail address: patilmeena64@ gmail.com
} 